International Research Journal of Management, IT \& Social Sciences
Available online at https://sloap.org/journals/index.php/irjmis/
Vol. 8 No. 2, March 2021, pages: 163-174
ISSN: 2395-7492
https://doi.org/10.21744/irjmis.v8n2.1376

\title{
Effect of Direct and Indirect Financial Compensation on Job Satisfaction
}

\begin{tabular}{|c|c|}
\hline & $\begin{array}{l}\text { Burhanudin } \\
\text { Richard Tambun }^{\mathrm{b}}\end{array}$ \\
\hline Article history: & Abstract \\
\hline $\begin{array}{l}\text { Submitted: } 27 \text { January } 2021 \\
\text { Revised: } 18 \text { February } 2021 \\
\text { Accepted: } 09 \text { March } 2021\end{array}$ & $\begin{array}{l}\text { This study aims to examine the effect of direct financial compensation on job } \\
\text { satisfaction and to examine the effect of indirect financial compensation on job } \\
\text { satisfaction. This type of research is quantitative research. Respondents in this } \\
\text { study were } 100 \text { employees at PT. Indonesia Asahan Aluminum (Persero), } \\
\text { Indonesia. The data collection technique used a questionnaire, while the data } \\
\text { analysis technique used multiple linear regression analysis. This study aims to }\end{array}$ \\
\hline \multirow[t]{2}{*}{$\begin{array}{l}\text { Keywords: } \\
\text { direct financial compensation; } \\
\text { indirect financial compensation; } \\
\text { job satisfaction; }\end{array}$} & $\begin{array}{l}\text { examine the effect of direct financial compensation on job satisfaction and } \\
\text { examine the effect of indirect financial compensation on job satisfaction. } \\
\text { Based on the results of this study, the company should make an appropriate } \\
\text { financial compensation policy, both direct and indirect financial compensation } \\
\text { to build employee job satisfaction. }\end{array}$ \\
\hline & $\begin{array}{r}\text { International research journal of management, IT and social sciences }(2021 . \\
\text { This is an open access article under the CC BY-NC-ND license } \\
\text { (https://creativecommons.org/licenses/by-nc-nd/4.0/). }\end{array}$ \\
\hline \multicolumn{2}{|c|}{$\begin{array}{l}\text { Corresponding author: } \\
\text { Burhanudin, } \\
\text { Faculty of Economics and Business, Janabadra University, Yogyakarta, Indonesia } \\
\text { Email address: burhanudin@janabadra.ac.id }\end{array}$} \\
\hline
\end{tabular}

${ }^{a}$ Faculty of Economics and Business, Janabadra University, Yogyakarta, Indonesia

Faculty of Economics and Business, Janabadra University, Yogyakarta, Indonesia 


\section{Introduction}

Currently, companies face various competitive challenges to be able to maintain their business. The competitive challenges faced by these companies include challenges of business continuity, global challenges, and challenges of technological advancement. Business continuity challenges are challenges faced by companies to survive and face dynamic competition. Global challenges are challenges faced by companies to compete with other companies from various countries in the world, both domestic and foreign companies. Meanwhile, the challenges of technological advancement are the challenges faced by companies in adapting to technology in their business activities.

To face these challenges, one of the strategies or ways that companies can do is to provide value to stakeholders such as shareholders, society, customers, and employees. One of the important values that contribute to the company is employee job satisfaction. Job satisfaction itself can be defined as a feeling of pleasure as a result of the perception that work can fulfill important work values for a person (Noe, Hollenbeck, Gerhart, \& Wright, 2008).

Job satisfaction can have a positive or negative impact on the organization or company. Satisfied employees tend to be more productive, have better performance or have behavioral organizational citizenship behavior. Conversely, dissatisfied employees tend to leave the company or have a higher rate of absence. For the company to gain a competitive advantage, it is necessary to manage the job satisfaction of its employees.

Job satisfaction is influenced by many factors. One of the factors that affect job satisfaction is financial compensation. Financial compensation consists of direct financial compensation and indirect financial compensation. This study aims to examine the effect of direct financial compensation and indirect financial compensation on job satisfaction. The subjects in this study were employees at PT. Indonesia Asahan Alumunium (Persero), North Sumatra, Indonesia.

Job satisfaction shows the level of a person's liking for his job. Formally, job satisfaction can be defined as an affective or emotional response to various aspects of a person's job. This definition implies that job satisfaction is not a concept of unity, but that someone may feel satisfied with one aspect of his job, but not satisfied with one or several other aspects. For example, an employee is satisfied with his coworkers, but not satisfied with his salary. Researchers at Cornell University developed a job description index (JDI) to assess a person's job satisfaction about job dimensions, namely the job itself, salary, promotion, co-workers, and supervision. Meanwhile, researchers at the University of Minnesota state that 20 different dimensions underlie one's job satisfaction. Although researchers do not have a consensus on the exact number of dimensions underlying job satisfaction, they do agree that there are five main causes of job satisfaction. Knowledge and understanding of the causes of job satisfaction can help managers use a multiaspect approach to improve employee job satisfaction (Kreitner \& Kinicki, 2014).

Compensation is the total of all awards given to employees in return for their services to the organization (Sinambela, 2016). According to Mondy \& Martocchio (2016) compensation is the total of all awards given to employees in return for their work. Compensation can be divided into two types, namely financial compensation and non-financial compensation. Financial compensation consists of direct financial compensation and indirect financial compensation. Direct financial compensation is the payment received by an employee in the form of salary, wages, commission, and bonus. Meanwhile, indirect financial compensation is all forms of compensation that are not included in direct financial compensation. This indirect financial compensation is also called employee benefits or benefits. This indirect financial compensation includes social security, unemployment compensation, workers compensation, paid rest time, health, life insurance, retirement plans, disability protection, employee stock option plans, employee services, and premium payments.

The second type of compensation is non-financial compensation. Non-financial compensation consists of the satisfaction received by an employee from the job itself and the environment, both the psychological environment and the physical environment where the person works (Mondy \& Martocchio, 2016). Non-financial compensation can be in the form of praise and appreciation, challenging work, promotion, job expansion, autonomy, self-development, career flexibility, comfort in duty, and so on (Al Fajar \& Heru, 2013; Kaswan, 2017).

One of the factors that affect employee job satisfaction is compensation such as salaries, wages, and allowances (Luthans, 2011; Colonnello et al., 2017; Lioui \& Sharma, 2012). The compensation given by the company to employees will affect their level of job satisfaction (Mangkunegara, 2017). Fair and reasonable compensation or rewards will affect employee job satisfaction.

Also, the purpose of providing compensation, among others, is to provide job satisfaction to employees. Because with compensation employees will be able to meet their life needs such as physical needs, social status, egoism, and so on so that employees will get job satisfaction from their position (Hasibuan, 2017; Shields et al., 2000; Song et al., 2020). Various studies have shown that compensation, especially financial compensation, affects job satisfaction. 
Amin (2014) found that financial compensation has a significant effect on employee job satisfaction. This research was conducted on 30 employees of the production division of the Sarinda bakery in Ambon city. Research conducted by Atmaja \& Maryatni (2019) on 75 employees of PT. Karya Prima Unggulan (Whsmith) in Kuta, Badung, found that financial compensation has a positive and significant effect on employee job satisfaction.

The results of research by Faliani et al. (2015) found that financial compensation has a significant effect on job satisfaction. This research was conducted on 65 employees of Tower (TWR) \& Approach - Terminal (APP-TMA) AirNavigasi (AirNav) Indonesia branch office of Aero Traffic Control (ATC) Soekarno Hatta Airport Jakarta. Kasra (2019) conducted a study with 141 employees as respondents at the PAM Tirta Mangkaluku Office, Palopo City. The results of his research indicate that financial compensation has a positive and significant effect on employee job satisfaction. Research conducted by Naser (2018) with the subject of 73 Employees at Karang Setra Hotel, Spa \& Cottages Bandung, West Java found that financial compensation has a significant effect on job satisfaction.

Nugraheni (2020) research results found that financial compensation has a positive effect on job satisfaction. Respondents in this study were 33 lecturers and staff of the Satya Wacana Christian University's Faculty of Language and Arts, Salatiga. Putra \& Mujiati (2016) research with the subject of 49 employees taking Japanese Restaurant Legian Kuta Badung Bali, found that financial compensation has a positive influence on employee job satisfaction.

Meanwhile, the research results of Rachmandika et al. (2016) found that financial compensation has a significant effect on job satisfaction. Respondents in this study were 98 employees of PT. Semen Indonesia (Persero) Tbk. Gresik, East Java. Research by Rizky et al. (2015) with the subject 72 employees of PT. Asuransi Jiwa Sinarmas MSIG, Pasuruan Branch, found that financial compensation has a significant effect on employee job satisfaction. The results of Rozi (2014) study found that financial compensation has a significant effect on job satisfaction. The subjects in this study were 57 employees at M-Brothers Group Lamongan.

The results of the research by Septerina \& Irawati (2018) found that financial compensation has a significant effect on job satisfaction. This research was conducted on 171 employees at the production department at PT. Etowa Packaging Indonesia. Research by Sholikhah et al. (2020) with the subject of 121 employees of the plate manufacturing subdivision of PT. Yuasa Battery Indonesia, also found that financial compensation has a positive and significant effect on employee job satisfaction. This study will investigate two forms of financial compensation, namely direct financial compensation and indirect financial compensation. The hypotheses proposed in this study are in Figure 1.

H1: direct financial compensation has a positive and significant effect on job satisfaction.

$\mathrm{H} 2$ : indirect financial compensation has a positive and significant effect on job satisfaction.

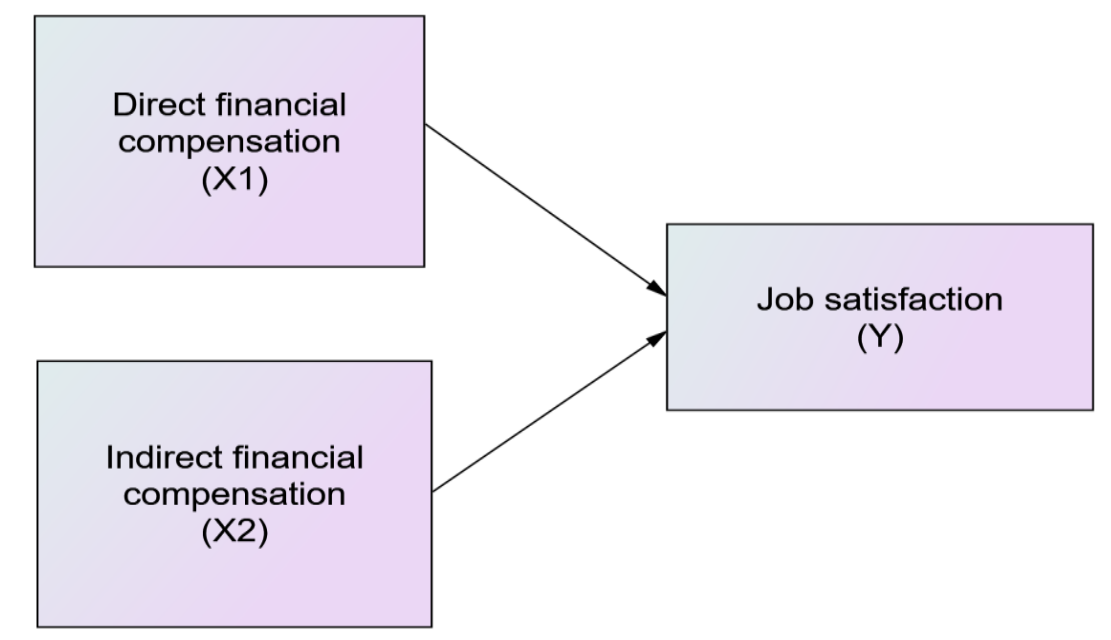

Figure 1. Theoretical Framework

Burhanudin, B., \& Tambun, R. (2021). Effect of direct and indirect financial compensation on job satisfaction. International Research Journal of Management, IT and Social Sciences, 8(2), 163-174. https://doi.org/10.21744/irjmis.v8n2.1376 


\section{Materials and Methods}

This type of research is quantitative research, which is a method for testing a theory by examining the relation ship between variables (Creswell, 2014). The paradigm in this study is the positivism paradigm, with a deductive approach (Saunders et al., 2009). The population in this study was 273 employees working in the operational division of PT. Indonesia Asahan Alumunium (Persero), North Sumatra, Indonesia. The sample size refers to Roscoe's opinion that a sample size greater than 30 and less than 500 is sufficient for all studies (Steele et al., 2013; Sekaran, 2006). Based on this opinion, the sample size in this study was 100 employees.

The variables in this study consisted of independent variables, namely direct financial compensation (X1) and indirect financial compensation (X2), and the dependent variable, namely job satisfaction (Y). The operational definitions of each variable are as follows.

a. Job satisfaction (Y) is an employee's level of preference for various aspects of his job (Kreitner \& Kinicki, 2014). Job satisfaction is measured by the Minnesota Satisfaction Questionnaire (MSQ) which consists of 20 question items. Responses were measured by a Likert scale, namely strongly disagree (score 1), disagree (score 2), neutral (score 3), agree (score 4), and strongly disagree (score 5).

b. Direct financial compensation (X1) is compensation in the form of basic salary, bonus, incentive, and allowance (Sinambela, 2016). Direct financial compensation is measured by 4 indicators consisting of 4 question items. Responses were measured by a Likert scale, namely strongly disagree (score 1), disagree (score 2), neutral (score 3 ), agree (score 4), and strongly disagree (score 5).

c. Indirect financial compensation (X2) is compensation in the form of health insurance, employment insurance, pensions, vacations, and facilities (Sinambela, 2016). Indirect financial compensation is measured by 5 indicators consisting of 10 question items. Responses were measured by a Likert scale, namely strongly disagree (score 1), disagree (score 2), neutral (score 3), agree (score 4), and strongly disagree (score 5).

Data collection was carried out using a questionnaire. The questions in the questionnaire are closed, meaning that alternative answers have been provided by the researcher so that the respondent only needs to choose the available alternative answers. The validity test is used to measure whether a questionnaire is valid or not. The validity and reliability tests were conducted with 30 respondents. A questionnaire is declared valid if the questions on the questionnaire can measure what the questionnaire will measure (Ghozali, 2016). The validity test in this study was carried out with the Pearson correlation coefficient. The criterion for the validity test uses a significance level of 0.05 , meaning that if the significance level generated by the Pearson correlation coefficient is smaller than 0.05 , the items are declared valid. The results of the validity test are presented in the following Table 1.

Table 1

Validity test result

\begin{tabular}{cccc}
\hline Variable & Item number & Sig. & Description \\
\hline Direct Financial Compensation (X1) & X1.1 & 0.000 & Valid \\
& X1.2 & 0.000 & Valid \\
& X1.3 & 0.000 & Valid \\
X1.4 & 0.000 & Valid \\
\hline Indirect financial compensation (X2) & X2.1 & 0.000 & Valid \\
& X2.2 & 0.000 & Valid \\
& X2.3 & 0.000 & Valid \\
& X2.4 & 0.000 & Valid \\
& X2.5 & 0.000 & Valid \\
& X2.6 & 0.000 & Valid \\
& X2.7 & 0.000 & Valid \\
& X2.8 & 0.000 & Valid \\
& X2.9 & 0.000 & Valid \\
& X2.10 & 0.000 & Valid \\
\hline Job satisfaction (Y) & Y1 & 0.000 & Valid \\
& Y2 & 0.000 & Valid \\
& Y3 & 0.000 & Valid \\
\hline
\end{tabular}




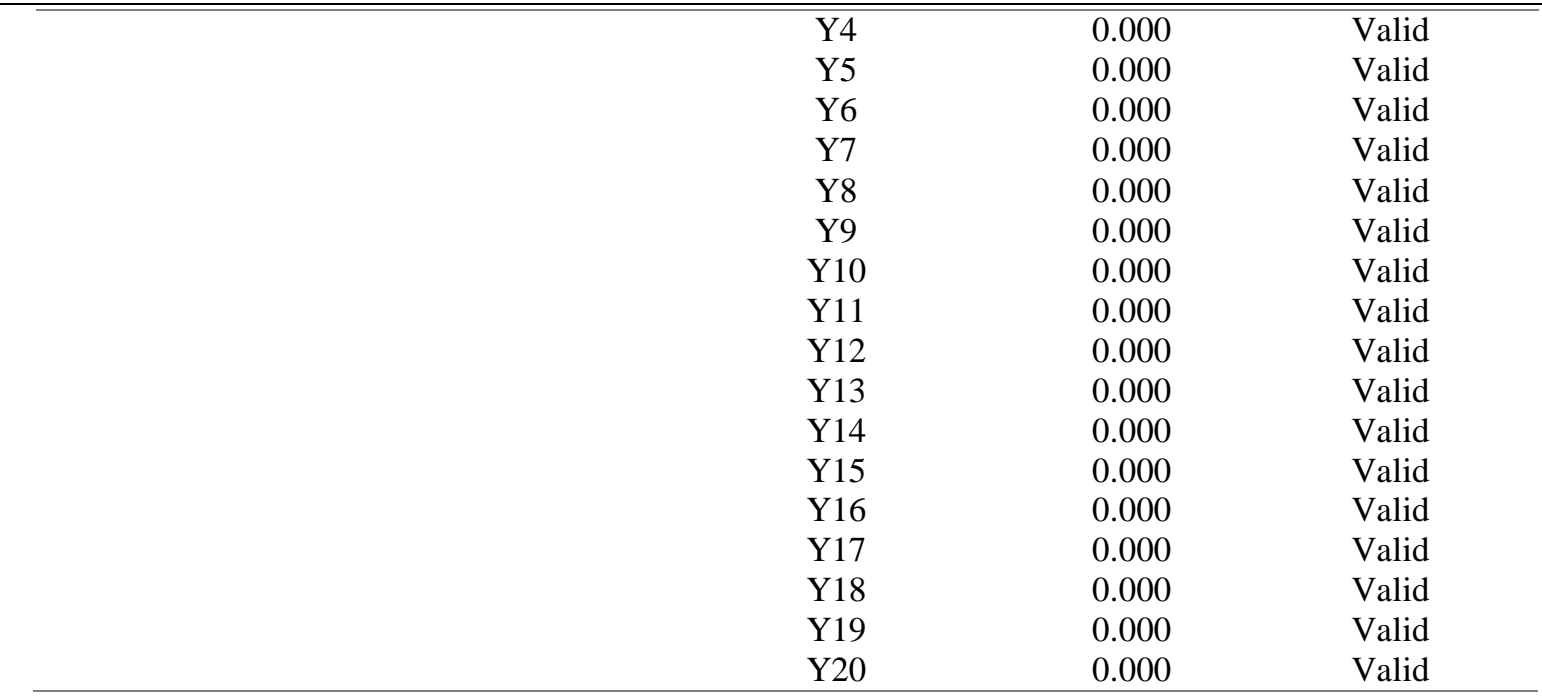

Source: processed data

Based on the results of the validity test, it appears that all items have a significantly smaller than 0.05 . Therefore, all items used in this study were declared valid. The next test is the reliability test. The reliability test was carried out by measuring just one shot (one-shot) with Cronbach's alpha. The criteria used are if the Cronbach alpha value is greater than 0.70 then the construct or variable is declared reliable (Ghozali, 2016). Reliability test results are presented in the following Table 2 .

Table 2

Reliability test result

\begin{tabular}{lll}
\hline Variable & Cronbach's Alpha & Description \\
\hline Direct Financial Compensation (X1) & 0,715 & Reliable \\
Indirect Financial Compensation (X2) & 0,968 & Reliable \\
Job Satisfaction (Y) & 0,976 & Reliable \\
\hline
\end{tabular}

Source: processed data

Based on the results of the reliability test, it appears that all variables have a Cronbach alpha value greater than 0.70 so that all variables used in this study are declared reliable. The data collected through a questionnaire will then be analyzed using multiple linear regression, with the following equation:

$$
\mathrm{Y}=\mathrm{b} 0+\mathrm{b} 1 \mathrm{X} 1+\mathrm{b} 2 \mathrm{X} 2
$$

Where:

- Y: job satisfaction.

- b0: constant.

- b1: direct financial compensation regression coefficient.

- b2: indirect financial compensation regression coefficient.

- X1: direct financial compensation.

- X2: indirect financial compensation.

Burhanudin, B., \& Tambun, R. (2021). Effect of direct and indirect financial compensation on job satisfaction. International Research Journal of Management, IT and Social Sciences, 8(2), 163-174. https://doi.org/10.21744/irjmis.v8n2.1376 


\section{Results and Discussions}

\section{Respondent characteristics}

Respondents in this study were 100 employees of PT. Indonesia Asahan Alumunium (Persero), North Sumatra, Indonesia. Respondent characteristics can be grouped by gender, level of education, and years of service. The characteristics of the respondents are presented in the following Table 3.

Table 3

Participant characteristics

\begin{tabular}{llll}
\hline Participant Characteristics & Category & Total & Percentage \\
\hline Gender & Male & 64 & $64 \%$ \\
& Female & 36 & $36 \%$ \\
Education & Junior High School (SMP) & 4 & $4 \%$ \\
& Senior High School (SMA/SMK\} & 51 & $51 \%$ \\
& Diploma (D3) & 9 & $9 \%$ \\
& Bachelor degree (S1) & 36 & $36 \%$ \\
Years of service & 2-5 years & 29 & $29 \%$ \\
& 6-9 years & 31 & $31 \%$ \\
& 10-13 years & 25 & $25 \%$ \\
Income & More than 13 years & 15 & $15 \%$ \\
& Less than IDR 3,000.000 & 12 & $12 \%$ \\
& IDR 3,000,0001- IDR 3,500,000 & 11 & $11 \%$ \\
& IDR 3,500,001- IDR 4,000,000 & 27 & $27 \%$ \\
Total & IDR 4,000,001- IDR 4,500,000 & 35 & $35 \%$ \\
\hline
\end{tabular}

Source: processed data

Based on the characteristics of the respondents, it appears that the number of male respondents is 64 employees, while the female respondents are 36 people. There are 4 respondents with the latest junior high school (SMP) education, 51 high schools (SMA/SMK), 9 diplomas (Diploma 3), and 36 respondents with a bachelor's degree (S1) as the last education. Respondents with a working period of 2 to 5 years were 29 people, working periods between 6 to 9 years were 31 people, working periods between 10 and 13 years were 25 people, and respondents with a work period of more than 13 years were 15 people employees.

Meanwhile, respondents with income less than IDR. 3,000,000 totaled 12 employees, respondents with income between IDR. 3,000,001 to IDR. 3,500,000 were 11 people, respondents with income between IDR. 3,500,001 to IDR. 4,000,000 were 27 people, respondents with an income of between IDR. 4,000,001 to IDR. 4,500,000 were 27 people, and respondents with an income of more than IDR. 4,000,000 were 15 people. Respondents in this study were dominated by male employees, with the latest SMA/SMK education, a work period of 6 to 9 years, and those with income between IDR. 4,000,001 to IDR. 4,500,000.

\section{Descriptive statistics}

Descriptive statistics in this study are used to provide an overview or description of research data, which can be seen from the minimum, maximum, mean, and standard deviation values. The results of the descriptive statistical analysis are presented in the following Table 4. 
Table 4

Descriptive statistics

\begin{tabular}{llllll}
\hline Variable & $\mathrm{N}$ & Min. & Max. & Mean & Std. Dev. \\
\hline Job satisfaction (Y) & 100 & 50 & 88 & 74.98 & 4.866 \\
Direct Financial Compensation (X1) & 100 & 11 & 19 & 15.70 & 1.673 \\
Indirect Financial compensation (X2) & 100 & 25 & 45 & 36.98 & 3.303 \\
Valid N (listwise) & 100 & & & & \\
\hline
\end{tabular}

Source: processed data

Based on the results of the descriptive statistical analysis, it appears that the number of respondents (N) is 100 employees. Of these 100 respondents, the minimum job satisfaction is 50 , the maximum is 88 , the average job satisfaction is 74.98 , and the standard deviation is 4,866. For direct financial compensation, the minimum value is 11 , the maximum is 19 , the average is 15.70 , and the foreign exchange standard is 1.673. Meanwhile, for indirect financial compensation, the minimum value is 25 , the maximum is 45 , the average is 36.98 , and the standard deviation is 3.303 .

\section{Multiple linear regression analysis}

The data analysis technique used in this study is to use multiple linear regression analysis. The accuracy of the regression function in interpreting the actual value can be measured by the goodness of fit, which consists of the coefficient of determination, the statistical value of $\mathrm{F}$, and the statistical value of $\mathrm{t}$ (Ghozali, 2016). A summary of the results of multiple linear regression analysis is presented in the following table

Table 5

Multiple linear regression analysis results

\begin{tabular}{|c|c|c|c|c|}
\hline \multirow[t]{2}{*}{ Model } & \multicolumn{2}{|c|}{ Unstandardized Coefficients } & \multirow[t]{2}{*}{$\mathrm{t}$} & \multirow[t]{2}{*}{ Sig. } \\
\hline & B & Std. Error & & \\
\hline 1 (Constant) & 37.888 & 5.583 & 6.787 & .000 \\
\hline Direct Financial Compensation & 1.175 & .246 & 4.773 & .000 \\
\hline Indirect financial compensation & .504 & .125 & 4.047 & .000 \\
\hline $\mathrm{F}$ & & & 22.863 & $.000^{\mathrm{b}}$ \\
\hline $\mathrm{R}$ & & & .566 & \\
\hline R Square & & & .320 & \\
\hline Adjusted R Square & & & .306 & \\
\hline
\end{tabular}

Dependent variable: job satisfaction

Predictors: (Constant): direct financial compensation, indirect financial compensation

Source: processed data

\section{Coefficient of determination}

The coefficient of determination is used to measure the extent of the model's ability to explain variations in the dependent or dependent variable (Ghozali, 2016). Based on the results of multiple linear regression analysis, it appears that the coefficient of determination (adjusted $\mathrm{R}$ square) is 0.306 . It can be interpreted that $30.6 \%$ of the variation in job satisfaction can be explained by the variation of two independent or independent variables, namely direct financial compensation and indirect financial compensation. While the rest, which is $69.4 \%$, is influenced by other causes or other variables outside the model in this study.

\section{Statistical test $F$}

The F statistical test or simultaneous significance test is used to test whether the regression model used can predict the dependent variable. Based on the results of the analysis, it appears that the significance value of 0.000 is smaller than 0.05. Therefore, the regression model used in this study can be used to predict job satisfaction, or in other words, direct financial compensation and indirect financial compensation together affect job satisfaction.

Burhanudin, B., \& Tambun, R. (2021). Effect of direct and indirect financial compensation on job satisfaction. International Research Journal of Management, IT and Social Sciences, 8(2), 163-174. 


\section{Statistical test $t$}

Based on the results of the t statistical test, it appears that the variable direct financial compensation and indirect financial compensation are significant with a value of 0.000 (less than 0.05 ). From the results of the $t$ statistical test, it turns out that the variable job satisfaction is influenced by direct financial compensation and indirect financial compensation. The regression equation is:

$$
\mathrm{Y}=37.888+1.175 \mathrm{X} 1+0.504 \mathrm{X} 2
$$

The regression equation can be interpreted as follows:

- A constant of 37.888 indicates that if the independent variable is considered constant, then the average job satisfaction is 37.888 .

- The direct financial compensation regression coefficient is 1.175 , which means that if there is an additional direct financial compensation of 1 unit, there will be an increase in job satisfaction by 1.175.

- The regression coefficient of indirect financial compensation is 0.504 which means that if there is an additional indirect financial compensation of 1 unit, there will be an increase in job satisfaction by 0.504 .

\section{Classic assumption test}

A regression model can be used to predict if it meets several assumptions that are often referred to as the classic assumption test (Santosa, 2015). The classic assumption test in this study consists of the multicollinearity test, heteroscedasticity test, and normality test.

The multicollinearity test aims to test whether the regression model used correlates with independent variables (Ghozali, 2016). The criteria used for the multicollinearity test are to look at the tolerance value and variance inflation factor (VIF). If the tolerance value is more than 0.10 and the VIF is less than 10 , then the model can be declared free from multicollinearity.

The multicollinearity test results of the direct financial compensation variable have a tolerance value of 0.979 (more than 0.10) and a VIF of 1.022 (less than 10). The indirect financial compensation variable has a tolerance value of 0.979 (more than 0.10) and a VIF of 1.022 (less than 10). Based on the multicollinearity test results, it can be stated that there is no multicollinearity between the independent variables in this study.

The heteroscedasticity test aims to test whether the regression model used is inequality of variants from the residuals of one observation to another (Ghozali, 2016). To determine the presence or absence of heteroscedasticity is to look at the plot graph between the predicted values of the dependent variable, namely ZPRED with the residual SRESID. To detect the presence or absence of heteroscedasticity, it can be done by looking at the presence or absence of a certain pattern in the scatterplot between SRESID and ZPRED, where the Y-axis is the predicted Y, and the Xaxis is the residual ( $\mathrm{Y}$ prediction - real $\mathrm{Y}$ ) that has been studied.

The basis for decision making is: (1) if there is a certain pattern, such as the dots forming a certain regular pattern (wavy, widened then narrowed), then there is an indication of heteroscedasticity; and (2) if there is no clear pattern, and the dots spread above and below the number 0 on the Y axis, then there is no heteroscedasticity (Ghozali, 2016). The results of the heteroscedasticity test show that the dots spread randomly both above and below the number 0 on the Y-axis. This indicates that there is no heteroscedasticity in the regression model used in this study.

The last classic assumption test is the normality test. This test is carried out to test whether, in the regression model, confounding or residual variables have a normal distribution (Ghozali, 2016). The normality test was carried out by the Kolmogorov Smirnov (KS) nonparametric test using the monte Carlo approach. The test results show that the monte Carlo sig (2-tailed) value of 0.645 is greater than 0.05 , this indicates that the data used in this study are normally distributed.

\section{Hypothesis testing 1}

Hypothesis testing in this study is based on the significance value. If the significance value is less than 0.05 , the hypothesis is supported. There are two hypotheses to be tested in this study. Hypothesis 1 testing is as follows.

- H0: direct financial compensation does not affect job satisfaction.

- H1: direct financial compensation has a positive and significant effect on job satisfaction. 
- Based on the results of the $t$ statistical test, it turns out that direct financial compensation has a significance value of 0.000 less than 0.05 . Therefore hypothesis 1 which states that direct financial compensation has a positive and significant effect on job satisfaction, is supported in this study.

\section{Hypothesis testing 2}

Hypothesis 2 that will be tested in this study are:

- H0: indirect financial compensation does not affect job satisfaction.

- H2: indirect financial compensation has a positive and significant effect on job satisfaction.

- Based on the results of the $t$ statistical test, it turns out that direct financial compensation has a significance value of 0.000 less than 0.05 . Therefore hypothesis 2 which states that financial compensation does not directly have a positive and significant effect on job satisfaction is supported in this study.

The results of this study indicate that direct financial compensation and indirect financial compensation affect employee job satisfaction. The results of this study support research conducted by Amin (2014), Rozi (2014), Atmaja \& Sri Maryatni (2019), Faliani et al. (2015), Kasran (2019), Naser (2018), Nugraheni (2020), Putra \& Mujiati (2016), Rachmandika et al. (2016), Septerina \& Irawati (2018), and Sholikhah et al. (2020), who found that financial compensation affects job satisfaction.

According to Luthans (2011) salary or wages and benefits (financial compensation) are one of the factors that affect employee job satisfaction. In this study, financial compensation consists of direct financial compensation and indirect financial compensation. Direct financial compensation consists of basic salary, bonuses, incentives, and allowances, while indirect financial compensation includes health insurance, employment insurance, pension plans, holidays, and facilities such as safe and comfortable parking spaces (Sinambela, 2016).

Financial compensation is very important for both employees and companies. For employees, financial compensation is the main source of income as well as their financial security. Financial compensation is an indicator of their status or success in the organization as well as in society. Financial compensation is also a reflection of a person's self-worth or worth. For companies, financial compensation is a powerful tool to achieve the company's strategic goals. Compensation has a large impact on employee attitudes and behavior. Financial compensation is a significant cost for the company, so it requires high accuracy. Financial compensation policies have a lot to do with various considerations for determining compensation. The size of the financial compensation is usually related to the level of education, position, years of service, and so on. Therefore, in determining financial compensation these factors need to be considered (Mangkunegara, 2017; Noe, Hollenbeck et al., 2008).

Financial compensation is important because adequate financial compensation will have an impact on job satisfaction. Adequate financial compensation can help companies to acquire and retain productive employees. Conversely, inadequate financial compensation will have an impact on employee dissatisfaction, which in turn will have an impact on reducing employee productivity or performance, increasing complaints, strikes, moving to companies, and other bad impacts (Kaswan, 2017).

\section{Conclusion}

Based on the results of this study, it can be concluded that: (a) direct financial compensation has a positive and significant effect on job satisfaction. This means that if direct financial compensation is increased, employee job satisfaction will increase; and (b) indirect financial compensation has a positive and significant effect on employee job satisfaction. This means that if financial compensation is not directly increased, employee satisfaction will also increase.

Theoretically, this study contributes to the literature by revealing the causal relationship between the independent variables, namely direct financial compensation and indirect financial compensation with the dependent variable, namely job satisfaction. Also, the results of this study provide recommendations for companies to determine effective financial compensation policies, both direct financial compensation and indirect financial compensation, to increase employee job satisfaction.

This study has many limitations. The limitations of this study include: (a) the subjects used in this study are limited to employees at PT. PT. Indonesia Asahan Alumunium (Persero), North Sumatra, Indonesia. Therefore, for further research, it is better to use different subjects or populations in organizations or companies, and in different areas; (b)

Burhanudin, B., \& Tambun, R. (2021). Effect of direct and indirect financial compensation on job satisfaction. International Research Journal of Management, IT and Social Sciences, 8(2), 163-174. https://doi.org/10.21744/irjmis.v8n2.1376 
the predictor variables used in the study are limited to direct financial compensation and indirect financial compensation. For further research, it is better to use other predictor variables such as working conditions, workgroup, promotion, personality factors, and so on.

\section{Conflict of interest statement}

The authors declared that they have no competing interests.

Statement of authorship

The authors have a responsibility for the conception and design of the study. The authors have approved the final article.

\section{Acknowledgments}

We are grateful to two anonymous reviewers for their valuable comments on the earlier version of this paper. 


\section{References}

Al Fajar, S., \& Heru, T. (2013). Manajemen Sumber Daya Manusia: Sebagai Dasar Meraih Keunggulan Bersaing. Yogyakarta: UPP STIM YKPN.

Amin, M. (2014). Pengaruh Kompensasi Finansial dan Kompensasi Non Finansial terhadap Kepuasan Kerja Karyawan Bagian Produksi Pabrik Roti Sarinda Kota Ambon. Akuntansi Bisnis \& Manajemen (ABM), 21(2), 97-109.

Atmaja, I. K. S., \& Maryatni, N. P. S. (2019). Pengaruh Kompensasi Finansial Dan Lingkungan Kerja Fisik Terhadap Kepuasan Kerja Karyawan Pada Pt. Karya Prima Unggulan (Whsmith) Di Kuta, Badung. Wacana Ekonomi (Jurnal Ekonomi, Bisnis Dan Akuntansi), 18(1), 17-25.

Colonnello, S., Curatola, G., \& Hoang, N. G. (2017). Direct and indirect risk-taking incentives of inside debt. Journal of Corporate Finance, 45, 428-466. https://doi.org/10.1016/j.jcorpfin.2017.05.012

Creswell, J. W. (2014). Research Design Pendekatan Kualitatif, Kuantitatif, Dan Mixed (3rd ed.). Yogyakarta: Pustaka Pelajar.

Faliani, A., Mukzam, M. D., \& Ruhana, I. (2015). Pengaruh Kompensasi Finansial Dan Kompensasi Non Finansial Terhadap Kepuasan Kerja Karyawan (studi Pada Karyawan Divisi Tower \&approach-Terminal (TWR\&APPTMA) Airnav Indonesia Kantor Cabang Aero Traffic Control (ATC) Bandara Soekarno Hatta). Jurnal Administrasi Bisnis, 26(2), 1-9.

Ghozali, I. (2016). Aplikasi Analisis Multivariate dengan Program IBM SPSS 23 (8th ed.). Semarang: Badan Penerbit Universitas Diponegoro.

Hasibuan, M. S. P. (2017). Manajemen Sumber Daya Manusia (Revisi). Jakarta: Bumi Aksara.

Kasran, M. (2019). Pengaruh Kompensasi Finansial Dan Kompensasi Non Finansial Terhadap Kepuasan Kerja Karyawan Pada Kantor Pam Tirta Mangkaluku Kota Palopo. Journal of Institution and Sharia Finance, 2(1), 4252.

Kaswan. (2017). Psikologi Industri \& Organisasi. Bandung: Alfabeta.

Kreitner, R., \& Kinicki, A. (2014). Organizational Behavior (9th ed.). New York: Mc Graw-Hill Education.

Lioui, A., \& Sharma, Z. (2012). Environmental corporate social responsibility and financial performance: Disentangling direct and indirect effects. Ecological Economics, 78, 100-111. https://doi.org/10.1016/j.ecolecon.2012.04.004

Luthans, F. (2011). Organizational Behavior: An Evidence-Based Approach. (12th ed.). New York: Mc Graw-Hill Irwin.

Mangkunegara, A. P. (2017). Manajemen Sumber Daya Manusia Perusahaan. Bandung: Remaja Rosdakarya.

Mondy, R. W., \& Martocchio, J. J. (2016). Human Resource Management (14th ed.). England: Pearson Education Ltd.

Naser, H. (2018). Pengaruh Kompensasi Finansial Dan Kompensasi Non-Finansial Terhadap Kepuasan Kerja Karyawan Di Karang Setrahotel, Spa \& Cottages-Bandung, Jawa Barat. Aliansi: Jurnal Manajemen Dan Bisnis, 13(2), 51-64.

Noe, R. A., Hollenbeck, J. R., Gerhart, B., \& Wright, P. M. (2008). Human Resource Management: Gaining a Competitive Advantage (6th ed.). New York: Mc Graw-Hill.

Nugraheni, A. D. P. (2020). Pengaruh Kompensasi Finansial dan Kompesasi Non Finansial terhadap Kepuasan Kerja Karyawan (Studi Pada Dosen dan Staf Fakultas Bahasa dan Seni UKSW Salatiga). Jurnal Ekobis Dewantara, 3(1), 11-19.

Putra, I. P. P., \& Mujiati, N. W. (2016). Pengaruh Kompetensi, Kompensasi Finansial dan Motivasi Kerja pada Kepuasan Kerja Karyawan Take Japanese Restaurant Legian Kuta Badung Bali. E-Jurnal Manajemen Universitas Udayana, 5(1), 260-292.

Rachmandika, I., Al Musadieq, M., \& Mayowan, Y. (2016). Pengaruh Kompensasi Finansial Dan Kompensasi Non Finansial Terhadap Kepuasan Kerja Karyawan (Studi Pada Karyawan PT Semen Indonesia (Persero) Tbk). Jurnal Administrasi Bisnis, 33(1), 9-17.

Rizky, W. P., Hakam, M. S., \& Nurtjahjono, G. E. (2015). Pengaruh Kompensasi Finansial Dan Non Finansial Terhadap Kepuasan Kerja Karyawan (Studi Pada Karyawan PT. Asuransi Jiwa Sinarmas Msig Cabang Pasuruan). Jurnal Administrasi Bisnis, 19(1), 1-7.

Rozi, F. (2014). Pengaruh Kompensasi Finansial dan Non Finansial Terhadap Kepuasan Kerja Karyawan (Studi Pada M-Brother Group Lamongan). Jurnal Administrasi Bisnis, 17(2), 1-10.

Santosa, S. (2015). Mengasai Statistik Parametrik Konsep Dan Aplikasi Dengan Spss. Jakarta: Elex Media Komputindo.

Saunders, M., Lewis, P., \& Thornhill, A. (2009). Research Methods for Business Students (5th ed.). Essex: Pearson Education Ltd.

Burhanudin, B., \& Tambun, R. (2021). Effect of direct and indirect financial compensation on job satisfaction. International Research Journal of Management, IT and Social Sciences, 8(2), 163-174.

https://doi.org/10.21744/irjmis.v8n2.1376 
Sekaran, U. (2006). Research Methods for Business (4th ed.). Jakarta: Salemba Empat.

Septerina, S., \& Irawati, R. (2018). Pengaruh Kompensasi Terhadap Kepuasan Kerja Karyawan Pada Bagian Produksi Di Pt. Etowa Packaging Indonesia. Journal of Applied Business Administration, 2(1), 13-19.

Shields, M. D., Deng, F. J., \& Kato, Y. (2000). The design and effects of control systems: tests of direct-and indirecteffects models. Accounting, Organizations and Society, 25(2), 185-202. https://doi.org/10.1016/S03613682(99)00041-0

Song, Y., Yang, T., Li, Z., Zhang, X., \& Zhang, M. (2020). Research on the direct and indirect effects of environmental regulation on environmental pollution: Empirical evidence from 253 prefecture-level cities in China. Journal of Cleaner Production, 269, 122425. https://doi.org/10.1016/j.jclepro.2020.122425

Steele, J. R., Rashford, B. S., Foulke, T. K., Tanaka, J. A., \& Taylor, D. T. (2013). Wolf (Canis lupus) predation impacts on livestock production: direct effects, indirect effects, and implications for compensation ratios. Rangeland Ecology \& Management, 66(5), 539-544. https://doi.org/10.2111/REM-D-13-00031.1

Sholikhah, Andriani, M., \& Aminah, H. (2020). Pengaruh Pengembangan Karir Dan Kompensasi Finansial Terhadap Kepuasan Kerja Subdivisi Plate Manufacturing Pt Yuasa Battery Indonesia. JRMSI-Jurnal Riset Manajemen Sains Indonesia, 11(1), 106-129.

Sinambela, L. P. (2016). Manajemen Sumber Daya Manusia: Membangun Tim Kerja yang Solid untuk Meningkatkan Kinerja. Jakarta: Bumi Aksara. 